Article

\title{
Gas Diffusion Electrodes Manufactured by Casting Evaluation as Air Cathodes for Microbial Fuel Cells (MFC)
}

\author{
Sandipam Srikanth, Deepak Pant, Xochitl Dominguez-Benetton, Inge Genné, \\ Karolien Vanbroekhoven, Philippe Vermeiren and Yolanda Alvarez-Gallego * \\ Separation and Conversion Technology, Flemish Institute for Technological Research (VITO), Boeretang 200, \\ MOL B-2400, Belgium; srikanth.sandipam@gmail.com (S.S.); deepak.pant@vito.be (D.P.); \\ xochitl.dominguez@vito.be (X.D.-B.); inge.genne@vito.be (I.G.); karolien.vanbroekhoven@vito.be (K.V.); \\ vermeirenphilippe@gmail.com (P.V.) \\ * Correspondence: yolanda.alvarezgallego@vito.be; Tel.: +32-1433-6941
}

Academic Editor: Federico Bella

Received: 30 April 2016; Accepted: 11 July 2016; Published: 21 July 2016

\begin{abstract}
One of the most intriguing renewable energy production methods being explored currently is electrical power generation by microbial fuel cells (MFCs). However, to make MFC technology economically feasible, cost efficient electrode manufacturing processes need to be proposed and demonstrated. In this context, VITO has developed an innovative electrode manufacturing process based on film casting and phase inversion. The screening and selection process of electrode compositions was done based on physicochemical properties of the active layer, which in turn maintained a close relation with their composition A dual hydrophilic-hydrophobic character in the active layer was achieved with values of $\varepsilon_{\text {hydrophilic }}$ up to $10 \%$ while $\varepsilon_{\text {TOTAL }}$ remained in the range $65 \mathrm{wt} \%$ to $75 \mathrm{wt} \%$. Eventually, selected electrodes were tested as air cathodes for MFC in half cell and full cell modes. Reduction currents, up to $-0.14 \mathrm{~mA} \cdot \mathrm{cm}^{2-}$ at $-100 \mathrm{mV}$ (vs. $\mathrm{Ag} / \mathrm{AgCl}$ ) were reached in long term experiments in the cathode half-cell. In full MFC, a maximum power density of $380 \mathrm{~mW} \cdot \mathrm{m}^{-2}$ was observed at $100 \Omega$ external load.
\end{abstract}

Keywords: gas diffusion electrode (GDE); bioelectrochemical systems (BES); microbial fuel cells (MFC); oxygen reduction reaction (ORR); low cost electrodes

\section{Introduction}

Microbial fuel cells (MFCs) are devices that produce electricity by means of oxidizing organic matter using microorganisms as catalyst at the anode. The electrons are transferred from the surface of a biocatalyst to the anode and then to the cathode through an external load, while, the ions (protons) migrate through an ion conducting or ion permeable membrane, or through the electrolyte between the electrodes. At the cathode, these electrons are accepted by an electron acceptor (mostly oxygen) in presence of the reducing equivalents (e.g., protons) to produce an electro-reduced substance (e.g., water, hydrogen peroxide) [1,2].

Similar to the anode, cathodes also play a very crucial role in enhancing the power output of MFCs by regulating the terminal reduction reaction. Various types of cathodes have already been tested for application in MFC, such as wet proofed carbon cloth, carbon fibers, graphite granules, carbon paper, $\mathrm{Pt}$, Au covered $\mathrm{Cu}$ wires, graphite felt, graphite rod, graphite foam, graphite plate, carbon felt, activated charcoal, drilled graphite discs, reticulated vitreous carbon (RVC), etc. [3-8]. On the other hand, a variety of chemo/bio/electro catalysts also have been investigated as alternative cathodic catalysts in air-cathode MFCs $[9,10]$. Interestingly, uncatalyzed activated carbon has shown promising performance for the oxygen-reduction reaction (ORR) when compared to $\mathrm{Pt}$ [11]. Since low solubility 
of oxygen in aqueous solutions is one of the main problems, limiting the ORR by mass transfer, the use of gas diffusion electrodes (GDE) appears a promising option. GDE have large reaction areas and allow for higher mass transfer rates [12].

The development of porous gas diffusion electrodes (GDEs) for electrochemical cells containing a free electrolyte liquid phase typically relies on complex manufacturing techniques based on pressing, cold rolling and stepwise assembly of the different layers $[13,14]$. In order to make microbial electrochemical systems (MES) feasible in large scale applications, further work should aim at increasing not only the immediate efficiency of the biofuel cell electrode (by improving the chemistry), but also to consider the engineering problems [5]. It is imperative to produce the electrodes in a cheap manner and in sizeable dimensions instead of using costly materials and batch wise fabrication processes $[15,16]$. VITO has developed an electrode manufacturing process based on film casting and phase inversion $[17,18]$. The film casting technique makes it possible to produce large multilayered electrodes in a single run with a continuous manufacturing process. An important issue is that this film casting technique allows for different manufacturing steps to be varied in order to adapt the structure and the composition of the cast layers to any specific requirement, mostly depending on the application [19].

The most relevant variables are the characteristics of the active component (chemical composition, particle size, surface area, etc.), the characteristics of the polymer binder, and the ratio of active component to polymer binder. Other essential parameters are the type and the amount of solvent in the casting dope, the type of non-solvent in the extraction bath, the use of additional pore forming agents, the casting thickness and finally the extraction temperature $[20,21]$. The influence of several of these manufacturing parameters has already been studied and described in detail for mixed matrix organic-inorganic membranes based on $\mathrm{ZrO}_{2}$ and polysulfone [22,23].

In the study presented here, we have endeavored to produce air diffusion cathodes implementing the casting and phase inversion manufacturing method, and to evaluate their performance for application in MFC. The electrodes studied in this work consist of three layers, viz., a current collector, an electrochemically active layer (AL), and a hydrophobic gas diffusion layer (HGDL). The electrochemical reduction of $\mathrm{O}_{2}$ from air is performed in the AL. Its porosity is therefore of major importance. Furthermore, one should make a clear distinction between hydrophobic porosity and hydrophilic porosity. Indeed hydrophilic pores are required for the absorption of the electrolyte (e.g., wastewater) and the hydrophobic porosity is needed for the transport of air $\left(\mathrm{O}_{2}\right)$ to the active sites of the carbon. The air is supplied to this AL through the HGDL, which also serves to avoid leakages, commonly referred to as weeping of the electrode [24-27].

\section{Results and Discussion}

\subsection{Physico-Chemical Characterization of the Active Layer ( $A L$ )}

The physicochemical properties of different types of AL were examined and compared to select the most promising electrode compositions for evaluation in a real MFC environment. The structure of the typical cross-section of an AL (75 wt \% C-25 wt \% PSf) and a HGDL (75 wt \% FEP-25 wt \% PSf) manufactured by casting are shown in Figure 1, left and right respectively. 


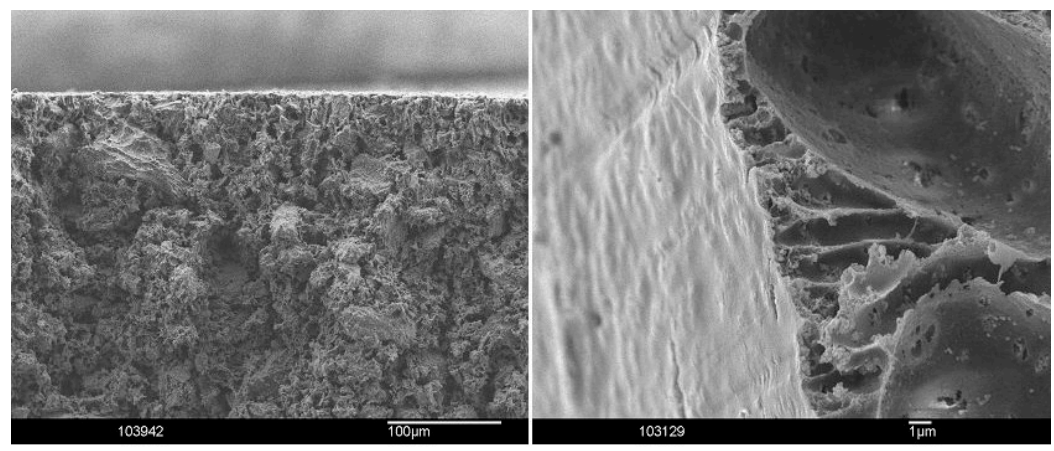

(a)

(b)

Figure 1. SEM image of the cross-section of a cast AL (a) and a cast HGDL (b).

\subsubsection{Influence of Fabrication Method on the Properties of the Active Layer}

The properties of ALs with the same ratio active carbon to polymer, but based on different fabrication methods are presented in Table 1. It is noteworthy that varying the manufacturing technique implies changing the polymer binder: whereas PTFE is the polymer binder for VITO CoRE ${ }^{\mathrm{TM}}$ electrodes, PSf is the binder used for VITO CaSETM electrodes. Both ALs compared in Table 1 were composed of $80 \mathrm{wt} \%$ of active carbon (Norit ${ }^{\circledR} \mathrm{SX} 1 \mathrm{G}$ ) and $20 \mathrm{wt} \%$ of the respective polymer. A surprising observation is that, although it has the lowest available porosity $\left(\varepsilon_{\text {TOTAL }}\right.$ ), the VITO CoRE ${ }^{\mathrm{TM}}$ AL (based on PTFE as a binder) absorbs more water than the VITO CaSETM AL. Indeed, since PTFE is the polymer with the lowest surface energy, it was expected that the PTFE based AL would be the most hydrophobic layer, with the lowest $\mathrm{H}_{2} \mathrm{O}$ absorption. On the contrary, this PTFE based AL absorbed much more water than the VITO CaSE ${ }^{\mathrm{TM}}$ AL (based on PSf). The explanation for this result is related to the amount of uncovered hydrophilic $\mathrm{C}$ during the manufacturing of an $\mathrm{AL}$, a certain amount of active carbon $\left(\mathrm{S}_{\mathrm{BET}}: 745 \mathrm{~m}^{2} \cdot \mathrm{g}^{-1}\right)$ is covered by the polymer. An AL with a high inner surface area is thus an indication that a large amount of this hydrophilic $\mathrm{C}$ remains uncovered and available to absorb $\mathrm{H}_{2} \mathrm{O}$.

Table 1. Influence of polymer binder and fabrication method on the properties of the active layer (composition $80 \mathrm{wt} \% \mathrm{C:20} \mathrm{wt} \%$ polymer).

\begin{tabular}{|c|c|c|c|c|c|c|c|}
\hline Polymer & $\begin{array}{c}\text { Surface Energy } \\
\text { (Polymer), } \\
\mathrm{mN} \cdot \mathrm{m}^{-1}\end{array}$ & $\begin{array}{c}\text { Thickness, } \\
\text { cm }\end{array}$ & $\begin{array}{c}\text { Resistance, } \\
\Omega \cdot \mathrm{cm}\end{array}$ & $\underset{\%}{\mathcal{E}_{\text {hydrophilic }}}$ & $\begin{array}{c}\mathcal{E}_{\text {TOTAL }} \\
\%\end{array}$ & $\begin{array}{c}\mathrm{S}_{\mathrm{BET}} \\
\mathrm{m}^{2} \cdot \mathrm{g}^{-1}\end{array}$ & $\begin{array}{l}\text { Pore Diameter, } \\
\mu \mathrm{m}\end{array}$ \\
\hline PSf & 41 & 0.0357 & 194 & 10 & 65 & 230 & 0.5 \\
\hline PTFE & 20 & 0.0510 & 14 & 29 & 66 & 454 & 0.1 \\
\hline
\end{tabular}

Another advantage of the VITO CoRE ${ }^{\mathrm{TM}} \mathrm{AL}$ is its electric resistance, being notably lower than that of the VITO CaSE ${ }^{\mathrm{TM}}$ electrode (Table 1). This can be explained by the fact that the amount of connections between the electrically conducting carbonaceous particles increases with the share of uncovered carbon in the AL. The pore diameters listed in Table 1 are the mean flow pore diameters as determined with capillary flow porosimetry, i.e., continuous pores connecting both surfaces of the active layer. As a result of the very high pressures applied during the manufacturing process, the ALs fabricated by cold rolling (based on PTFE as a binder) feature an average pore diameter about one order of magnitude smaller than that of the active layer fabricated by casting. 


\subsubsection{Effect of Composition of the Coagulation Bath on the Properties of the Active Layer}

A comparative evaluation of the effect of the composition of the coagulation bath on the porosity of the active layer was performed for ALs composed of $70 \mathrm{wt} \%$ active carbon powder (Norit ${ }^{\circledR} \mathrm{SX}-1 \mathrm{G}$ ) $+30 \mathrm{wt} \%$ of PSf (12 wt \% in NEP) as the binding polymer. As already discussed, the properties and structure of the porous active layer can be affected by the kinetics of the solvent extraction process during which the AL of the electrode is being formed. Amongst other things, the extraction kinetics is dependent on the composition of the non-solvent. The effect of two non-solvents was investigated: pure water for a fast extraction and a mixture of $75 \mathrm{wt} \% \mathrm{NMP}+25 \mathrm{wt} \%$ water for a slow extraction. These results are shown in Table 2.

Table 2. Influence of the composition of the coagulation bath and of the type of active carbon used on the properties of the cast active layer (composition $70 \mathrm{wt} \% \mathrm{C}: 30 \mathrm{wt} \% \mathrm{PSf}$ ).

\begin{tabular}{|c|c|c|c|c|c|c|c|}
\hline Non-Solvent & $\begin{array}{c}\text { Type of Carbon } \\
\text { Powder }\end{array}$ & $\begin{array}{c}\text { Thickness, } \\
\text { cm }\end{array}$ & $\begin{array}{c}\text { Resistance, } \\
\Omega \cdot \mathrm{cm}\end{array}$ & $\begin{array}{c}\mathrm{Aw}, \\
\mathrm{mg} \cdot \mathrm{cm}^{-2} \cdot \mathrm{s}^{-1 / 2}\end{array}$ & $\begin{array}{c}\mathcal{E}_{\text {hydrophilic }} \\
\%\end{array}$ & $\begin{array}{c}\varepsilon_{\text {TOTAL }}, \\
\%\end{array}$ & $\begin{array}{l}\mathrm{S}_{\mathrm{BET}}, \\
\mathrm{m}^{2} \cdot \mathrm{g}^{-1}\end{array}$ \\
\hline $\mathrm{H}_{2} \mathrm{O}$ & Norit SX1G & 0.076 & 145 & 0.27 & 8 & 74 & 207 \\
\hline $\mathrm{H}_{2} \mathrm{O}$ & Printex & 0.068 & 321 & - & 1 & 72 & 18 \\
\hline $\mathrm{NMP} / \mathrm{H}_{2} \mathrm{O}$ & Norit SX1G & 0.070 & 99 & 0.34 & 9 & 73 & 172 \\
\hline $\mathrm{NMP} / \mathrm{H}_{2} \mathrm{O}$ & Printex & 0.066 & $\mathrm{~nm}$ * & - & 0.5 & 65 & 15 \\
\hline
\end{tabular}

The most striking result observed was that using a solvent/non-solvent mixture in the coagulation bath hardly affected the hydrophilic porosity; for ALs with the same composition, the hydrophilic pore volume ( $\left.\varepsilon_{\text {hydrophilic }}\right)$ was very low when compared with the total porosity, as calculated from the iso-propanol absorption ( $\varepsilon_{\text {TOTAL }}$ ). The higher specific surface area, as obtained with the fast $\mathrm{H}_{2} \mathrm{O}$ extraction, is an indication that here more active carbon (and thus electrochemically reactive sites) is available for the redox reactions to occur. The other characteristics are not quite dependent on the type of extraction bath that is being used.

\subsubsection{Effect of the Type of Activated Carbon on the Properties of the Active Layer}

The properties of active layers as a function of the type of carbonaceous active powder and the composition of the coagulation bath were studied and are presented in Table 2. The specific surface area of the Norit ${ }^{\circledR} \mathrm{SX}-1 \mathrm{G}$ type of $\mathrm{C}$ is as high as $745 \mathrm{~m}^{2} \cdot \mathrm{g}^{-1}$ with 50 mass-percent of the particles smaller than $25 \mu \mathrm{m}$. For the sake of comparison, Printex ${ }^{\circledR} 25$ an alternative type of carbonaceous active powder with a specific surface area $\left(45 \mathrm{~m}^{2} \cdot \mathrm{g}^{-1}\right)$ was investigated along with Norit ${ }^{\circledR} \mathrm{SX} 1 \mathrm{G}$. The highest specific surface areas were obtained with the extractions in water and the highest wettability (expressed as $\varepsilon_{\text {hydrophilic }}$ ) was observed for the layers based on Norit ${ }^{\circledR}$ SX1G. Among these, the layer prepared using water as coagulation bath was selected for further investigation. Figure 2a shows the pore size distribution of an AL based on Norit ${ }^{\circledR} \mathrm{SX} 1 \mathrm{G}$ as active powder and a pure water coagulation bath. The highest relative pore volume is situated at pore diameter ca. $1 \mu \mathrm{m}$. 


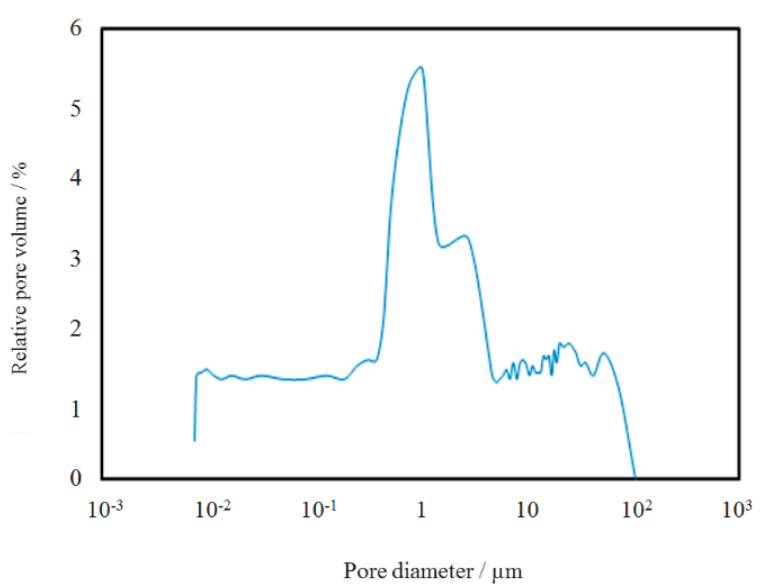

(a)

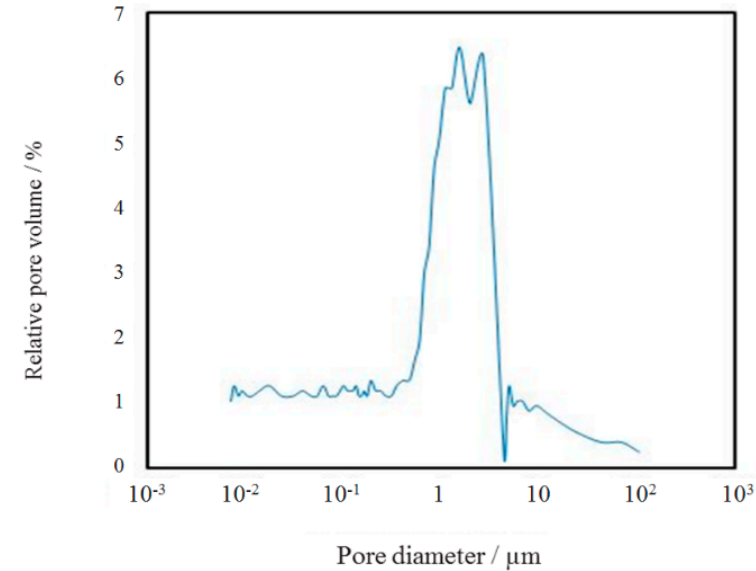

(b)

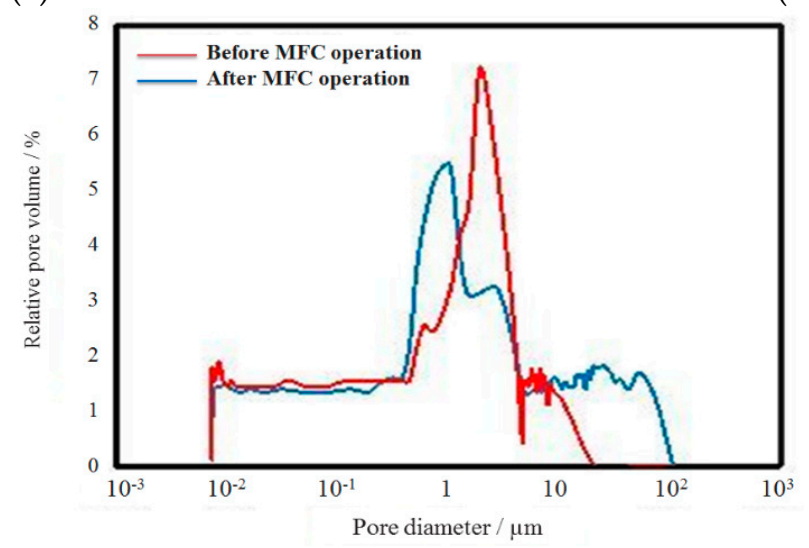

(c)

Figure 2. (a) Pore size distribution of a HGDL with composition FEP:PSf 75:25; (b) Pore size distribution of an AL/SS without HGDL (determined by Hg intrusion porometry); (c) Effect of MFC operation on pore size diameter.

\subsubsection{Effect of Active Carbon Contents on the Properties of the AL}

Three different ratios C:PSf were explored, using pure water as coagulation bath (Table 3). The results clearly show a decrease of the resistance of the AL on increasing the $\mathrm{wt} \% \mathrm{C}$ contents. This is expected because the amount of connections between the electrically conducting carbon particles increases with the amount of carbonaceous powder present in the AL. Other properties such as porosity, specific surface area $\left(\mathrm{S}_{\mathrm{BET}}\right)$ or the water absorption coefficient $(\mathrm{A})$ did not vary significantly as a function of wt $\% \mathrm{C}$ content within the composition span investigated.

Table 3. Effect of wt \% carbon on the properties of the cast active layer (AL).

\begin{tabular}{|c|c|c|c|c|c|c|}
\hline$C$, wt $\%$ & $\begin{array}{c}\text { Thickness, } \\
\text { cm }\end{array}$ & $\begin{array}{c}\text { Resistance, } \\
\Omega \cdot \mathrm{cm}\end{array}$ & $\begin{array}{c}\mathrm{Aw}, \mathrm{mg} \\
\mathrm{cm}^{-2} \mathrm{~s}^{-1 / 2}\end{array}$ & $\mathcal{E}_{\text {hydrophilic' }}$ & $\begin{array}{c}\mathcal{E}_{\text {TOTAL }} \\
\quad \%\end{array}$ & $\begin{array}{c}\mathrm{S}_{\mathrm{BET}}, \\
\mathrm{m}^{2} \cdot \mathrm{g}^{-1}\end{array}$ \\
\hline 65 & 0.071 & 655 & 0.42 & 8 & 73 & 177 \\
\hline 70 & 0.076 & 145 & 0.27 & 8 & 74 & 207 \\
\hline 75 & 0.067 & 86 & 0.33 & 10 & 70 & 201 \\
\hline
\end{tabular}

\subsection{Physico-Chemical Characterization of the Hydrophobic Gas Diffusion Layer (HGDL)}

The ability of the HGDL to prevent electrolyte leakage was evaluated ex-situ. The results are presented in Table 4 . The layers tested in these experiments had two free surfaces instead of normally one. Because of the phase inversion manufacturing procedure a cast porous layer always exhibits two 
different surfaces: a surface with an open porosity, in contact with the support, and the top surface with a dense porosity [14-20], Figure 1b. During the water permeability experiments, extremely small amounts of water could penetrate inside the different structures but the dense layer at the low pressure side was the ultimate water barrier for every single HGDL. The water absorption was almost independent of the composition of the HGDLs and was as low as about $3 \mu \mathrm{L} \cdot \mathrm{cm}^{-2} \cdot \mathrm{h}^{-} \cdot \mathrm{Pa}^{-1}$, even for the HGDL based on pure PSf.

Table 4. Effect of the additional polymers on the properties of the HGDL.

\begin{tabular}{|c|c|c|c|c|c|c|}
\hline $\begin{array}{l}\text { Polymer } \\
\text { Additive }\end{array}$ & wt $\%$ & $\begin{array}{l}\text { Thickness, } \\
\text { cm }\end{array}$ & $\begin{array}{l}\text { Mean Pore Size } \\
\text { (CFP), } \mu \mathrm{m}\end{array}$ & $\underset{\%}{\mathcal{E}_{\text {hydrophilic }}}$ & $\begin{array}{c}\mathcal{E}_{\text {TOTAL }}, \\
\%\end{array}$ & $\stackrel{L_{P},}{L \cdot h^{-1} \cdot \mathrm{cm}^{-2} \cdot \operatorname{bar}^{-1} \cdot 10^{6}}$ \\
\hline FEP & 0 & 0.091 & 0.405 & 32 & 79 & 3.6 \\
\hline FEP & 10 & 0.097 & 0.162 & 28 & 78 & 3.7 \\
\hline FEP & 20 & 0.096 & 0.202 & 27 & 81 & 1.7 \\
\hline FEP & 40 & 0.106 & 0.115 & 15 & 75 & 2.8 \\
\hline FEP & 60 & 0.103 & 0.159 & 7 & 74 & 2.5 \\
\hline FEP & 70 & 0.107 & 0.116 & 4 & 73 & 2.8 \\
\hline FEP & 80 & 0.117 & 0.136 & 3 & 66 & 4.2 \\
\hline $\begin{array}{l}\text { PTFE } \\
\text { Algoflon }\end{array}$ & 10 & 96 & 0.358 & 21 & 80 & 3.7 \\
\hline PTFE 636N & 10 & 0.105 & 0.137 & 24 & 63 & 4.1 \\
\hline
\end{tabular}

A series of freestanding HGDLs with a systematic variation in the ratio of hydrophobic particles to PSf was produced and tested. Table 4 shows that the hydrophilic character decreased with increasing amounts of hydrophobic polymer particles. The lower the permeability values, the lower the leakage or amount of weeping of electrolyte that can be expected as a function of time. The HGDL containing

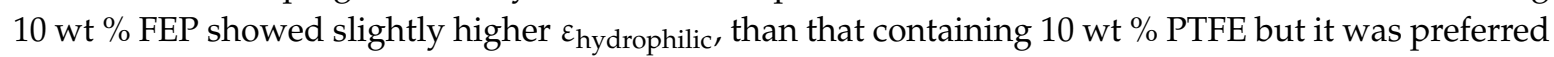
for its superior processability. Compared with the pure PSf HGDL, the addition of the hydrophobic polymer particles resulted in a considerable improvement in the efficiency of the HGDL (in terms of impermeability to electrolyte), which was confirmed during in-situ testing in electrochemical cells.

Figure 1a shows the surface of the hydrophobic layer. The section on the right shows that, just beneath the surface, small stretched pores are present. On average these slit shaped pores have a diameter of only about $1 \mu \mathrm{m}$. Going deeper into the structure the picture shows the hydrophobic FEP particles as they are dispersed in the PSf matrix. The pore size distribution is shown in Figure $2 b$ and confirms the average surface pore size distribution as observed in Figure $1 \mathrm{~b}$. The total porosity of the HGDLs, as measured with isopropanol, is almost independent of the amount of hydrophobic polymer in the PSf layer and is situated at a level of ca. $70 \pm 10 \mathrm{vol} \%$ of the layer. This value enables a sufficient flow for the air to access the active layer of the electrode.

\subsection{Electrode Characterization in Cathodic Half-Cell Environment}

\subsubsection{Electrode Polarization}

The $\mathrm{O}_{2}$ reduction reaction on the cathode half cell set-up proceeds as follows: $\mathrm{pH}<7$

$$
\mathrm{O}_{2}+4 \mathrm{H}^{+}+4 \mathrm{e}^{-} \rightarrow 2 \mathrm{H}_{2} \mathrm{O}
$$

$\mathrm{pH}>7$

$$
\mathrm{O}_{2}+2 \mathrm{H}_{2} \mathrm{O}+4 \mathrm{e}^{-} \rightarrow 4 \mathrm{OH}^{-}
$$

with $\mathrm{E}=1.007-0.05916 \mathrm{pH}$ vs. $\mathrm{Ag} / \mathrm{AgCl}$ at $25^{\circ} \mathrm{C}$ and $\mathrm{P}_{\mathrm{O} 2}=0.1$

$\mathrm{O}_{2}$ reduction reaction can also lead to the synthesis of hydrogen peroxide:

$\mathrm{pH}<7$

$$
\mathrm{O}_{2}+2 \mathrm{H}^{+}+2 \mathrm{e}^{-} \rightarrow \mathrm{H}_{2} \mathrm{O}_{2}
$$


$\mathrm{pH}>7$

$$
\mathrm{O}_{2}+\mathrm{H}_{2} \mathrm{O}+2 \mathrm{e}^{-} \rightarrow \mathrm{HO}_{2}^{-}+\mathrm{OH}^{-}
$$

For $2 \mathrm{e}^{-}$reduction half- reactions $\mathrm{E}$ are $700 \mathrm{mV}$ and $-65 \mathrm{mV}$ vs. SHE [24] (i.e., $500 \mathrm{mV}$ and $-260 \mathrm{mV}$ vs. $\mathrm{Ag} / \mathrm{AgCl}$ ) respectively. Their equilibrium is also $\mathrm{pH}$ dependent. Subsequent reduction of $\mathrm{H}_{2} \mathrm{O}_{2}$ into water can also take place.

$\mathrm{pH}<7$

$$
\mathrm{H}_{2} \mathrm{O}_{2}+2 \mathrm{H}^{+}+2 \mathrm{e}^{-} \rightarrow \mathrm{H}_{2} \mathrm{O}
$$

$\mathrm{pH}>7$

$$
\mathrm{HO}_{2}^{-}+\mathrm{H}_{2} \mathrm{O}+2 \mathrm{e}^{-} \rightarrow 3 \mathrm{OH}^{-}
$$

E for reactions (5) and (6) are $1760 \mathrm{mV}$ and $870 \mathrm{mV}$ vs. SHE [28] (i.e., $1560 \mathrm{mV}$ and $870 \mathrm{mV}$ vs. $\mathrm{Ag} / \mathrm{AgCl}$ ) respectively. An important issue which is often neglected in LSV experiments is the hysteresis and the complex shape of the voltammogram as shown in Figure 3.

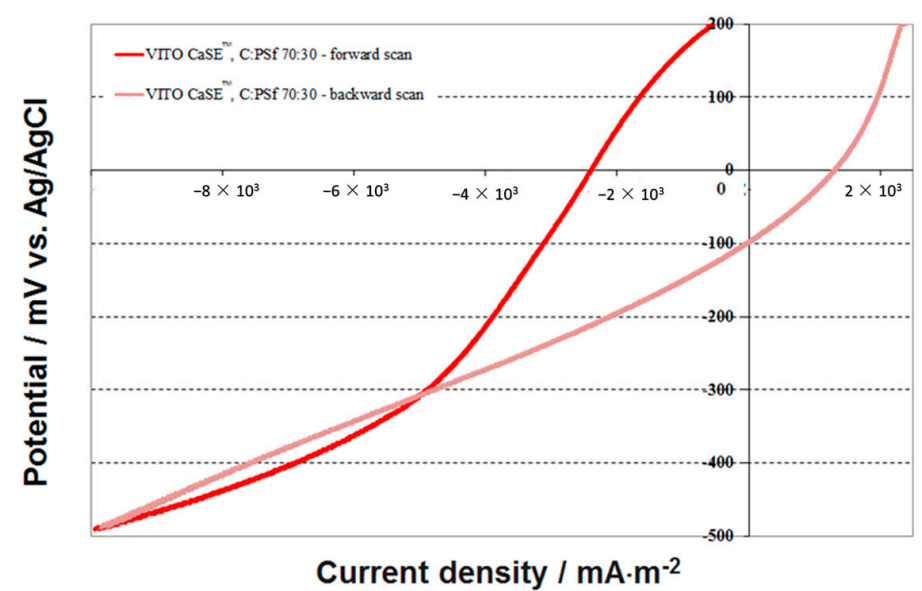

Figure 3. LSV traces for a VITO CaSE ${ }^{\mathrm{TM}}$ electrode (C:PSf 70:30), forward and backward scan (scan rate: $\left.1 \mathrm{mV} \cdot \mathrm{s}^{-1}\right)$.

This could be an indication that the system is not in equilibrium and that the results have only some indicative value. Also, the extent of the hysteresis can be related to the degree of adsorption, if the latter is a relevant step in the electrolytic mechanism as is the case for the $\mathrm{O}_{2}$ reduction reactions in porous carbon electrodes. The forward scan should be related to the reduction of $\mathrm{O}_{2}$ which is present in the electrolyte. It must be clear from half-reactions (1) and (2) that the $\mathrm{O}_{2}$ reduction potential is highly dependent on the $\mathrm{pH}$ of the electrolyte which in turn is dependent on the amount of charge flowing through the electrode; by the end of the forward scan the $\mathrm{pH}$ may have shifted by one unit; the same applies for half-reactions (3) and (5). It is also clear that both the $\mathrm{pH}$ and the resulting ionic resistance inside the very small pores of the electrode are not instantaneously at the level of the buffered and circulating bulk electrolyte. The same holds for the $\mathrm{O}_{2}$ concentration inside the pores because the $\mathrm{O}_{2}$ transport through both the HGDL and AL is too slow to compensate for the reduced amount of $\mathrm{O}_{2}$. Additionally the hydrophilic and/or hydrophobic groups on the pore surface may also affect the transport of the reacting compounds to the internal pores. The overall result is that during the scan, both the reversible potential and the polarization are continually changing; as a result, a pronounced hysteresis becomes inevitable, even after selecting an acceptably low scan rate as $1 \mathrm{mV} \cdot \mathrm{s}^{-1}$.

By the end of the backward scan the current becomes even positive at cathode potential higher than $-100 \mathrm{mV}$ vs. $\mathrm{Ag} / \mathrm{AgCl}$. This could be a further indication that during the forward scan, in parallel with the $\mathrm{O}_{2}$ reduction reaction to $\mathrm{H}_{2} \mathrm{O}$ some other reduction reaction (e.g., $\mathrm{O}_{2}$ reduction to $\mathrm{H}_{2} \mathrm{O}_{2}$ ) has taken place, the product being re-oxidised at the higher potential. Redox reactions taking place at the functional groups of activated carbon may also contribute to this phenomenon to a minor extent. 
The effect of the operational conditions has been determined both on the electrochemical performance and on the physico-chemical properties of the AL. The tested VITO CaSE ${ }^{\mathrm{TM}}$ electrode was composed of a current collector, an AL (70 wt \% Norit and $30 \mathrm{wt} \% \mathrm{PSf}$ ), but no HGDL. For this experiment no HGDL was applied because it is not possible to determine the physico-chemical properties of an active layer if it is covered with a HGDL. After 14 days the cell was dismantled to evaluate the physicochemical parameters of the electrode and compare them with those of a fresh electrode. The most remarkable result is that only $14 \mathrm{vol} \%$ of a fresh electrode can be filled with water whereas after operation in the MFC this volume is as high as about $44 \mathrm{vol} \%$. This is a clear indication that the electrode has become much more hydrophilic, probably related to the evolution of carbon-oxygen or carbon-ORR-adsorbed intermediates. These may create additional vacancies and, combined with the adsorption of impurities inside the pores of the electrode, lead to the formation of stable defect complexes in which water can be further captured. Comparison of the pore size distribution of the electrode before and after MFC operation (Figure 2c) shows that the relative volume of the first peak is reduced in favor of the relative volume of the second peak. This could indicate that the small pores are involved in the complexation of oxygen and carbon vacancies, which is likely the origin of the increased hydrophilicity of the electrode.

Figure 4 presents the LSV traces registered for two VITO CaSETM electrodes. For comparison purposes, results on the VITO CoRE ${ }^{\mathrm{TM}}$ electrode from reference [29] are presented as well.

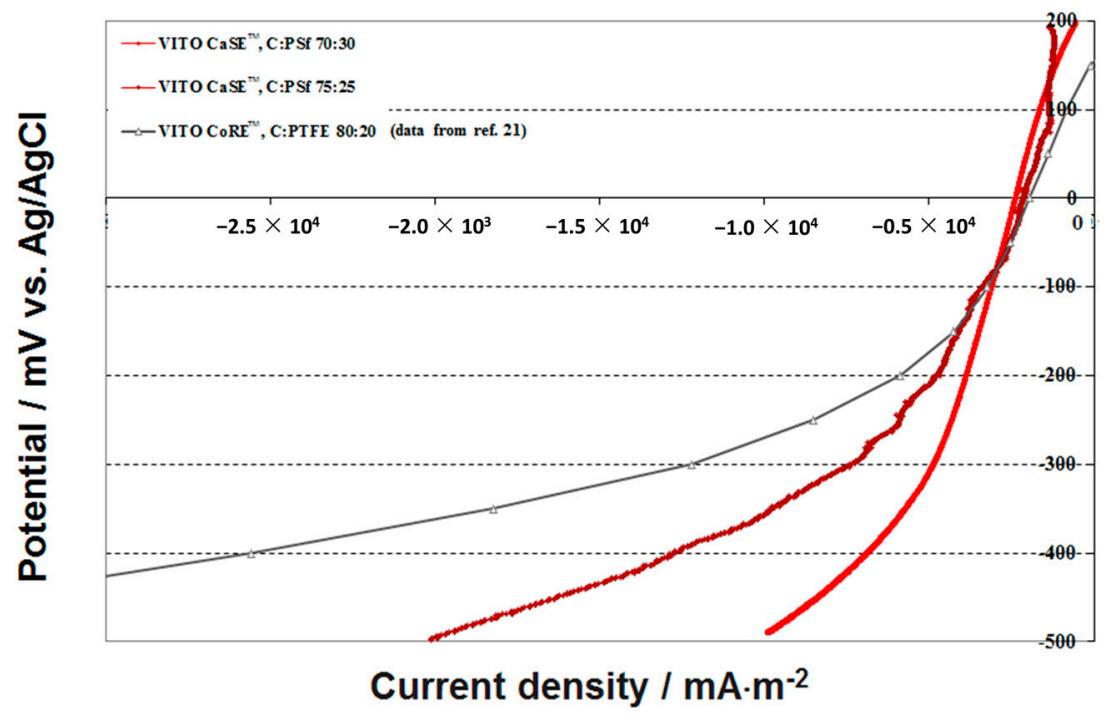

Figure 4. Effect of the composition of the $\mathrm{AL}\left(\mathrm{C}\right.$ wt \%) on the performance of the VITO CaSE ${ }^{\mathrm{TM}}$ electrode.

At cathode potentials $-100 \mathrm{mV}$ vs. $\mathrm{Ag} / \mathrm{AgCl}$ all three electrodes produce a similar current density. As is discussed in Subsection 3.4, this region of cathode potential corresponds with the cell operating point leading to maximum power density. The amount of $\mathrm{C}$ in the VITO CaSE ${ }^{\mathrm{TM}}$ electrodes becomes only relevant at potential lower than $-500 \mathrm{mV}$. It is also in that region that the calendered electrodes show superior performance compared to that of the VITO CaSE ${ }^{\mathrm{TM}}$ electrodes. It should be noted nonetheless that these current densities are on average ca. 10 times higher than the corresponding values from the long term tests (discussed below), which are performed at a constant electrode potential of $-100 \mathrm{mV}$ vs. $\mathrm{Ag} / \mathrm{AgCl}$.

\subsubsection{Electrode Performance as a Function of Time}

Two different compositions of VITO CaSE ${ }^{\mathrm{TM}}$ electrodes (C:PSf 75:25 and 70:30 in the AL respectively) and one VITO CoRE ${ }^{\mathrm{TM}}$ (C:PTFE 80:20 in the AL) electrode (C:PTFE 80:20 in the AL) were tested in continuous operation at constant potential for more than 100 days. Figure 5 clearly 
shows that both the VITO CaSE ${ }^{\mathrm{TM}}$ and VITO CoRE ${ }^{\mathrm{TM}}$ electrodes suffer from a quite severe performance loss during the first hours of operation. This is probably related to the equilibrium settings of the electro-active species inside the porous structure of the AL. During the first days of operation, the VITO CoRE ${ }^{\mathrm{TM}}$ electrode had a performance at a level of about $-1200 \mathrm{~mA} \cdot \mathrm{m}^{-2}$. This value of current density is in between the average performance of the VITO CaSETM electrode with AL C:PSf 70:30 (ca. $-800 \mathrm{~mA} \cdot \mathrm{m}^{-2}$ ) and that of the VITO CaSETM electrode with AL C:PSf 75:25 (ca. $-1400 \mathrm{~mA} \cdot \mathrm{m}^{-2}$ ). However, the current density obtained with the VITO CoRE ${ }^{\mathrm{TM}}$ electrode evolves towards the performance level of the worst performing VITO CaSETM electrode (AL C:PSf 70:30); after e.g., 50 days in operation the current densities for the VITO CoRE ${ }^{\mathrm{TM}}$ electrode and for the VITO CaSE $^{\mathrm{TM}}$ electrodes with AL C:PSf 75:25 and AL C:PSf 70:30 reached $-900 \mathrm{~mA} \cdot \mathrm{m}^{-2},-1260 \mathrm{~mA} \cdot \mathrm{m}^{-2}$ and $-660 \mathrm{~mA} \cdot \mathrm{m}^{-2}$ respectively. The steady decrease in performance was attributed to the adsorption of fouling in the pores of the electrodes, which takes place more readily in the VITO CoRE ${ }^{\mathrm{TM}}$ electrode than in the VITO CaSE ${ }^{\mathrm{TM}}$ electrode because the latter has a larger pore size. The nature of such deposits could be inorganic (e.g., salts coming from PBS), organic (originating from acetate), biologic (from inoculum) or a mixture thereof. A cleaning experiment was set up to verify this hypothesis. After ca. 2 months of operation the electrodes were cleaned by flushing the cells with demineralized water, unmounting the electrode from the cell, and cleaning them with fresh demi water. The electrodes were subsequently built and tested in the cell again. No clear effect could be observed for the VITO $\mathrm{CaSE}^{\mathrm{TM}}$ electrodes. In the case of the VITO CoRE ${ }^{\mathrm{TM}}$ electrode we concluded that fouling deposits were probably removed with the cleaning experiment, as its performance reverted to its initial level.

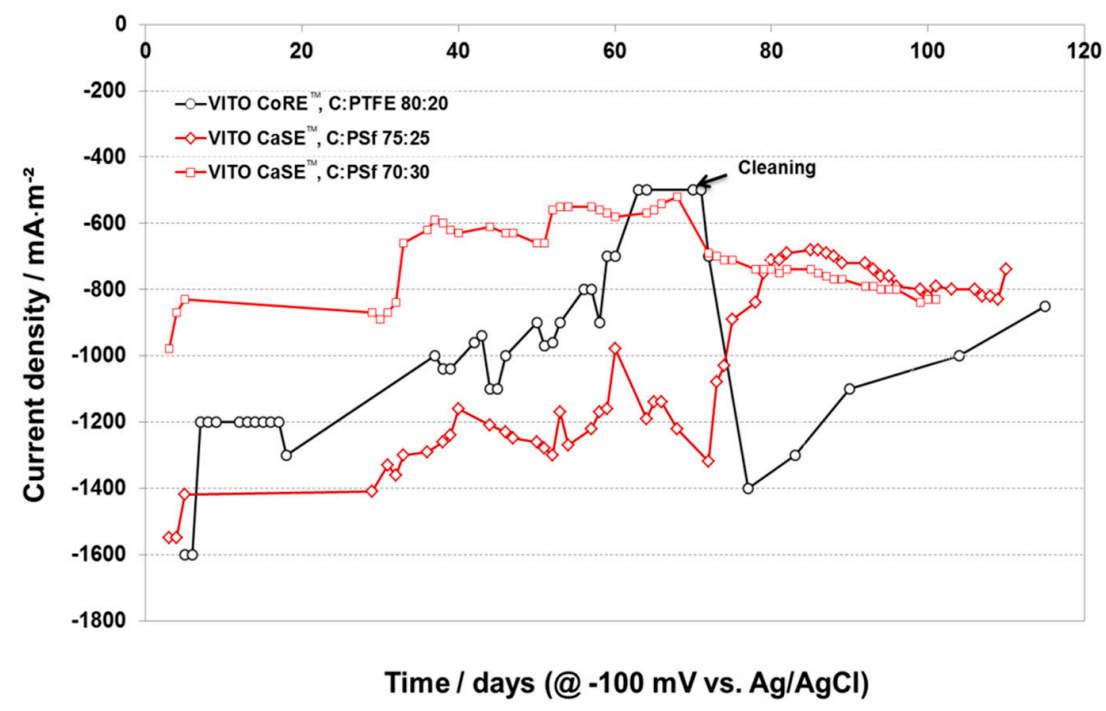

Figure 5. Performance of a VITO CaSE ${ }^{\mathrm{TM}}$ electrode (C:PSf 70:30) as a function of time at constant voltage $-100 \mathrm{mV}$ vs. $\mathrm{Ag} / \mathrm{AgCl}$.

\subsection{Electrode Performance in MFC (Full Cell Configuration)}

\subsubsection{Power Output and Half-Cell Potentials}

Anodic and cathodic half-cell potentials along with cell potential and current densities were measured during MFC operation in open circuit and closed circuit modes (Figure 6a). Anode potential should be as low and the cathode potential as high as possible for the maximized electrical energy output. This suggests the need of optimal anode and cathode potentials satisfying both the cell growth and energy output [30,31]. Immediately after start-up the cathode (VITO CaSE ${ }^{\mathrm{TM}}$ ) potential was about $190 \mathrm{mV}$ and was stable till the eighth day of operation where it showed a small drop to $145 \mathrm{mV}$ and stabilized until the circuit was closed. On the other hand, the value of anode potential was almost $0 \mathrm{mV}$ at the start. The value of anode potential gradually decreased until it reached $-500 \mathrm{mV}$ at the 
twelth day of operation, indicating a strong acetate oxidizing environment at the anode. As a result of this change in anode potential, the cell potential increased gradually from $190 \mathrm{mV}$ of start-up potential to $654 \mathrm{mV}$ of maximum performance. A sudden drop in fuel cell performance was observed after the twelfth day due to the depletion of substrate. After addition of substrate, all three potentials gradually recovered the maximum value in two days.

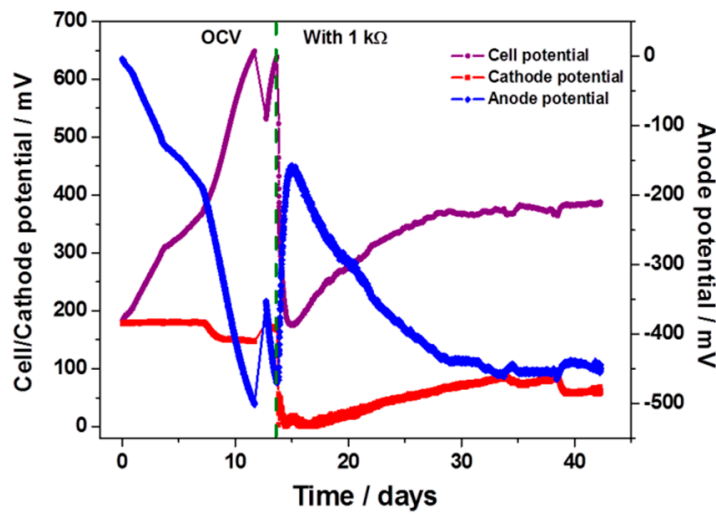

(a)

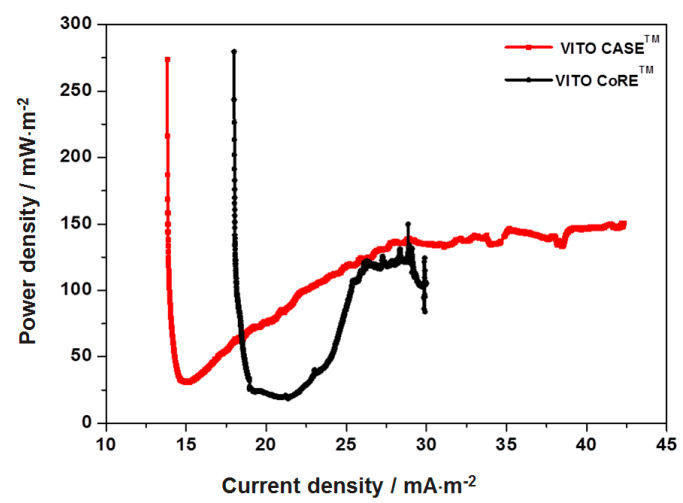

(b)

Figure 6. (a) Cell potential and anodic, cathodic half-cell potentials against time during MFC operation with VITO CaSE ${ }^{\mathrm{TM}}$ electrode as cathode; (b) Comparative power density profiles against time during MFC operation with VITO CoRE ${ }^{\mathrm{TM}}$ and VITO CaSE ${ }^{\mathrm{TM}}$ cathodes.

The cathode potential also showed a small drop with respect to the drop in anode potential but increased immediately after substrate addition. This shows the dependence of cathodic reduction on the anodic oxidation reaction. The MFC was then connected in closed circuit using $1 \mathrm{k} \Omega$ resistance to measure the current flow across the circuit (Figure 6a). Immediately after connecting in the circuit, within a few hours, the anode potential increased to $-150 \mathrm{mV}$ and the respective cathode potential dropped to near $0 \mathrm{mV}$, contributing to a drop in cell potential of up to $162 \mathrm{mV}$. Parallel to this, a current discharge was also observed in the circuit immediately after circuit closure $\left(535 \mathrm{~mA} \cdot \mathrm{m}^{-2}\right)$, which led to a power density of $274 \mathrm{~mW} \cdot \mathrm{m}^{-2}$ (Figure $6 \mathrm{~b}$ ). The high power density observed immediately after connecting the circuit is due to capacitive current rather than to microbial activities. The current density rapidly dropped to $164 \mathrm{~mA} \cdot \mathrm{m}^{-2}$ within hours and then started to increase slowly, reaching a stable value at the 30 th day of operation $\left(405 \mathrm{~mA} \cdot \mathrm{m}^{-2}\right.$ to $\left.435 \mathrm{~mA} \cdot \mathrm{m}^{-2}\right)$, contributing to a stable power output $\left(130 \mathrm{~mW} \cdot \mathrm{m}^{-2}\right.$ to $\left.150 \mathrm{~mW} \cdot \mathrm{m}^{-2}\right)$, till the end of operation. After the open circuit phase, the circuit was closed by means of applying a load of $1 \mathrm{k} \Omega$ causing the cathode potential to change notably in response to the current discharge. Immediately after connecting in the circuit, the cathode potential dropped to near zero and gradually increased until reaching the steady state potential of $88 \mathrm{mV}$ to $96 \mathrm{mV}$ at the 34th day of operation and was almost stable till the end of operation. The cathode potential took slightly more time to stabilize than the anode potential and current output. In a similar MFC set-up and operation conditions with the VITO CoRETM electrode as cathode, an almost similar power output was achieved $\left(135 \mathrm{~mW} \cdot \mathrm{m}^{-2}\right.$ to $\left.145 \mathrm{~mW} \cdot \mathrm{m}^{-2}\right)$, as recently reported by our group [26]. However, the cell potential was slightly higher compared to the CaSE ${ }^{\mathrm{TM}}$ operation; in this respect it should be noted that the VITO CoRE ${ }^{\mathrm{TM}}$ electrode has a higher carbon percentage in the AL than either of the VITO CaSE ${ }^{\mathrm{TM}}$ electrodes evaluated. The cathode potential was observed to be stable both with the VITO CaSETM electrode and the VITO CoRE ${ }^{\mathrm{TM}}$ electrode, suggesting that it is feasible to keep the cathode potential independent of anode functioning, as is expected for a single chamber MFC.

\subsubsection{Fuel Cell Characterization}

Once the power output was stabilized, polarization characteristics were recorded to evaluate the fuel cell behavior. After stabilization at $1 \mathrm{k} \Omega$ load, MFC was evaluated for its performance under 
varying external loads $(10 \mathrm{k} \Omega-10 \Omega)$. High external resistance solely limits the electron delivery to the cathode, while, at lower external resistance, the electron delivery to the cathode is limited by kinetic and/or mass transfer (or internal resistance). At the point where both the external and internal resistances become equalized, the power density shows a peak value, which is commonly the cell design point (CDP) of choice for MFCs [31]. Typical polarization behavior was observed with a gradual increment in power density with decreasing resistance up to (CDP) and then decreased afterwards with both the cathodes (Figure 7). Electron discharge from the biocatalyst to the anode is regulated by the external and internal resistances [32].

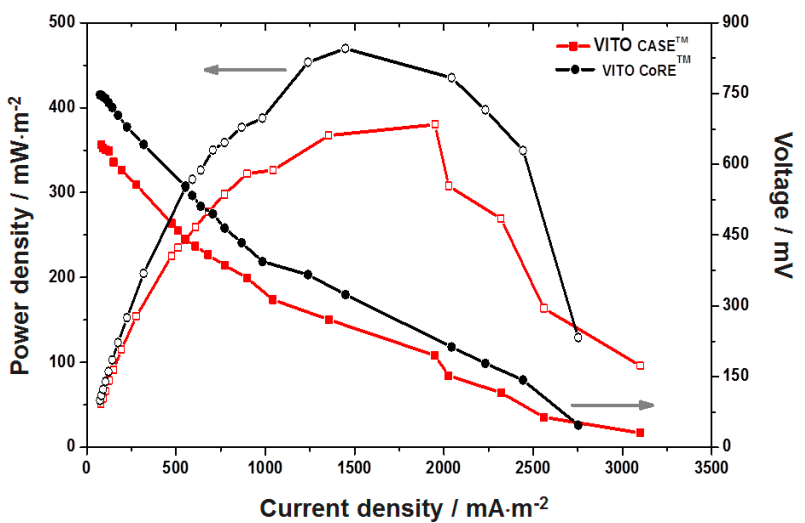

Figure 7. Comparative polarization profiles across varying external loads $(10 \mathrm{k} \Omega-10 \Omega)$ during MFC operation with VITO CoRE ${ }^{\mathrm{TM}}$ and VITO CaSETM cathodes.

The voltage drop at higher resistances was slow, stabilized faster, and regained the original voltage quicker after removing the load, while it was reverse at lower resistances. The voltage drop and electron discharge started visibly at $10 \mathrm{k} \Omega\left(68 \mathrm{~mA} \cdot \mathrm{m}^{-2}\right)$ and gradually increased to $3100 \mathrm{~mA} \cdot \mathrm{m}^{-2}$ at $10 \Omega$, accounting for a voltage drop of $31 \mathrm{mV}$. The CDP was observed at $100 \Omega$ with a voltage of $195 \mathrm{mV}$ and current density of $1950 \mathrm{~mA} \cdot \mathrm{m}^{-2}$, accounting for a power density of $380 \mathrm{~mW} \cdot \mathrm{m}^{-2}$. It is usual practice to operate fuel cells beyond CDP because the fuel cell will destabilize at higher current densities and low voltages. Similarly, the MFC operation with VITO CoRETM also showed a typical polarization behavior depicting an increment in current densities associated with voltage drop, as the resistance decreases. Electron discharge started visibly at $7 \mathrm{k} \Omega\left(105 \mathrm{~mA} \cdot \mathrm{m}^{-2}\right)$ and increased with lowering resistance till $10 \Omega\left(2750 \mathrm{~mA} \cdot \mathrm{m}^{-2}\right)$. The power density obtained with the VITO CoRE ${ }^{\mathrm{TM}}$ electrode increased when increasing the external resistance to reach a maximum when $200 \Omega$ was applied $\left(1450 \mathrm{~mA} \cdot \mathrm{m}^{-2} ; 469 \mathrm{~mW} \cdot \mathrm{m}^{-2}\right)$ and dropped thereafter. Though, the current density is lower than VITO CaSETM MFC, the power density was higher in this case, which is due to the regulation in voltage drop. The percentage of carbon in the AL is higher $(80 \%)$ in the VITO CoRE ${ }^{\mathrm{TM}}$ electrode than in the VITO CaSETM electrode $(70 \%)$, which allows the electrode to maintain a higher potential difference resulting in higher power density. However, the higher porosity in the gas diffusion layer of the VITO $\mathrm{CaSE}^{\mathrm{TM}}$ electrode allowed better gas diffusion. This ultimately leads to a higher reaction rate at the interface, resulting in slightly higher current densities.

\section{Materials and Methods}

\subsection{Materials}

Activated carbon powder was obtained from commercial sources Norit SX-1G (Norit B.V., Amersfoort, The Netherlands) and Printex 25 (Evonik Industries, Essen, Germany). Polysulfone (PSf, UDEL ${ }^{\circledR}$ P-1800 NT 11) was supplied by Solvay (Brussels, Belgium). PTFE Algoflon ${ }^{\circledR}$ was supplied by Solvay Solexis Spa (Bollate, Italy). Fluorinated ethylene-propylene copolymer (FEP 8000) and PTFE (type 636N) were purchased from DuPont de Nemours (Nederland) B.V. (Dordrecht, The Netherlands). 
Stainless steel (SS) 316L gauze (Solana, Schoten, Belgium) wire diameter $100 \mu \mathrm{m}$, mesh 44 was used as current collector.

\subsection{Manufacturing of the Gas Diffusion Cathodes}

The manufacturing of the complete VITO CaSE ${ }^{\mathrm{TM}}$ electrode comprises the steps of casting the AL onto the current collector and casting a hydrophobic gas diffusion layer HGDL onto the active layer. The process is described below for each of these two steps. For comparison purposes some results on the characterization of electrodes prepared by cold rolling (VITO CoRETM electrodes, VITO, Mol, Belgium) are presented as well. These electrodes are based on activated carbon and PTFE (type 636N, DuPont). The performance of these electrodes has already been described in detail earlier for various systems $[10,24-27,33,34]$.

\subsubsection{Active Layer (AL)}

For the manufacturing of the $\mathrm{AL}$, a solution of polysulfone in N-ethyl-pyrrolidone (NEP) is mixed with activated carbon powder. A typical active layer for MFC application is composed of $70 \mathrm{wt} \%$ active carbon and $30 \mathrm{wt} \%$ PSf. On the lab scale $48 \mathrm{~g}$ PSf was dissolved in $352 \mathrm{~g}$ of NEP, after which the PSf solution was mixed with $112 \mathrm{~g}$ of activated carbon. The suspension was subsequently deaerated at room temperature under static vacuum (50 mbara). The casting head was filled with the suspension which was then cast onto the support by means of longitudinal motion of the casting head. The wet active layer (supported with the current collector net) was next immersed in the coagulation bath. The active layer formed in the coagulation step was boiled in demineralized water to remove the residual solvent and non-solvent and dried overnight at room temperature.

\subsubsection{Hydrophobic Gas Diffusion Layer (HGDL)}

For the HGDL, hydrophobic polymer particles were added to a solution of $15 \mathrm{wt} \%$ PSf in NEP. The hydrophobic particles were FEP 8000, PTFE Algoflon or PTFE 636N. A typical HGDL is composed of $75 \mathrm{wt} \%$ of a hydrophobic material and $25 \mathrm{wt} \%$ PSf. The suspension to produce such HGDL is typically composed of $60 \mathrm{~g}$ PSf dissolved in $340 \mathrm{~g}$ NEP and $180 \mathrm{~g}$ of the hydrophobic polymer particles. For the rest, the same manufacturing procedure was used as described for the AL except that in this case the HGDL was cast onto the AL of the electrode.

\subsection{Manufacturing of Freestanding Layers}

Freestanding specimens of AL and of HGDL were manufactured and characterized for the screening of optimal compositions. These layers were prepared by casting on a glass plate as a temporary support, subjecting the cast layer to phase inversion by immersing in a coagulation bath and removing residual solvent by treating the layer in hot demi water over $1 \mathrm{~h}$ after separating the layers from their temporary support. When PSf was the only component for the HGDL, the water repellent performance was not satisfactory due to their relatively low hydrophobicity, resulting from the high surface area of PSf. In a second stage different amounts of hydrophobic polymer powders were added to the polysulfone solution in order to increase the hydrophobicity of the resulting layer. A series of different PSf based HGDLs incorporating increasing amounts of different hydrophobic polymer particles (from $5 \mathrm{up}$ to $80 \mathrm{wt} \%$ ) were manufactured and characterized. The thickness of the layers was measured with a Mitutoyo micrometer (Kawasaki, Japan). The thickness was measured at four different points in order to obtain a representative value. The freestanding ALs typically had a final thickness of ca. $700 \mu \mathrm{m}$. The freestanding HGDLs had a final thickness of ca. $100 \mu \mathrm{m}$.

\subsection{Physicochemical Characterization Techniques}

The procedure for the determination of hydrophilic porosity $\left(\varepsilon_{\text {hydrophilic }}, \%\right)$ and total porosity, $\left.\varepsilon_{\text {TOTAL }}, \%\right)$, and of the electric resistance of the free standing active layers has been described 
elsewhere [27]. Pore size distribution was determined by $\mathrm{Hg}$ intrusion porosimetry with a Pascal 240 Porosimeter (Thermo Electron Corporation, Waltham, MA, USA). Pore diameters were also determined by capillary flow porometry (CFP) using a PMI Capillary Flow Porometer 6.0 (Porous Materials Inc., New York, NY, USA). With the latter technique only the open pores going from one side of the layer to the other are measured.

The absorption coefficient (Aw, $\mathrm{mg} \mathrm{cm}^{-2} \cdot \mathrm{s}^{-1 / 2}$ ) was calculated for freestanding ALs from the amount of water absorbed by capillarity per surface unit $\left(\mathrm{mg} \cdot \mathrm{cm}^{-2}\right)$, as per Equation 7 :

$$
\mathrm{A}_{\mathrm{W}}=\frac{\mathrm{m}_{\mathrm{H} 2 \mathrm{O}, \mathrm{t}}}{\mathrm{S} \cdot \mathrm{t}^{1 / 2}}
$$

where $\mathrm{t}$ is the time $(\mathrm{s}), \mathrm{m}_{\mathrm{H} 2 \mathrm{O}, \mathrm{t}}(\mathrm{g})$ is the mass of water absorbed by the sample after time $\mathrm{t}$ of immersion and $S\left(\mathrm{~cm}^{2}\right)$ is the geometric area of the sample in contact with water.

The pore volume and the BET surface area $\left(\mathrm{S}_{\mathrm{BET}}\right)$ were obtained from $\mathrm{N}_{2}$ adsorption experiments (Nova 3000, Quantachrome, Boynton Beach, FL, USA), using Quantachrome NovaWin 2 (Version 2.2) for processing the data. Typical measuring protocol comprises degassing for $20 \mathrm{~h}$ at $120^{\circ} \mathrm{C}$, and subsequent measurement of the adsorption isotherm at $-196{ }^{\circ} \mathrm{C}$. Field emission scanning electron microscopy (FESEM) and EDS spectra were performed using a Jeol JSM-6340F (Peabody, MA, USA).

An in-house set up was used for the determination of water transport through the HGDL. The dry HGDLs were incorporated in a horizontal position into a Plexiglas cell (projected surface area $13.85 \mathrm{~cm}^{2}$ ), with the dense porosity at the low pressure side. A plastic tube on top of the cell was filled with water to apply a pressure difference across the dry HGDL sample. A typical experiment would proceed continuously over 3-5 days at room temperature. The transmembrane volumetric flux was determined from the very small reduction of the water level in the plastic tube on top of the cell (no trace of water could be observed at the bottom of the cell, underneath the HGDL sample). The water permeability Lp is defined as the volume of water that passes through a membrane per unit time, per unit area, and per unit of transmembrane pressure (8).

$$
L_{p}=\frac{J}{\Delta p}
$$

It was calculated by dividing the flux by the pressure at which it was measured, considering that $1 \mathrm{~m}$ water column accounts for $10 \mathrm{KPa}$.

\subsection{Electrode Characterization in Cathodic Half-Cell Configuration}

Characterization of the electrodes as oxygen (air) reducing cathode was carried out in an electrochemical half-cell under conditions analogous to those described in previous work [21]. Figure 8 is a schematic reresentation (side view) of the cathode half-cell used for the characterization of the electrodes. The projected surface area of the electrode was $10 \mathrm{~cm}^{2}$. The experiments were carried out at room temperature $\left(18^{\circ} \mathrm{C}\right)$. Air was fed at an overpressure of $5 \mathrm{mbarg}$. All values of electrode potential are reported versus $\mathrm{Ag} / \mathrm{AgCl}(3 \mathrm{M} \mathrm{KCl})$ reference electrode (+199 mV vs. SHE). Electrochemical measurements were performed using a potentiostat type VersaSTAT 3F (Princeton Applied Research, Oak Ridge, TN, USA) and the VersaStudio software (Princeton Applied Research, Oak Ridge, TN, USA) for data collection. Unless otherwise stated all the Linear Sweep Voltammetric (LSV) experiments were performed at a scan rate of $1 \mathrm{mV} \cdot \mathrm{s}^{-1}$. The electrode potentials were always scanned from $+200 \mathrm{mV}$ to $-500 \mathrm{mV}$ vs. $\mathrm{Ag} / \mathrm{AgCl}(3 \mathrm{M} \mathrm{KCl})$. The curves are shown for the forward scan unless otherwise noted. 


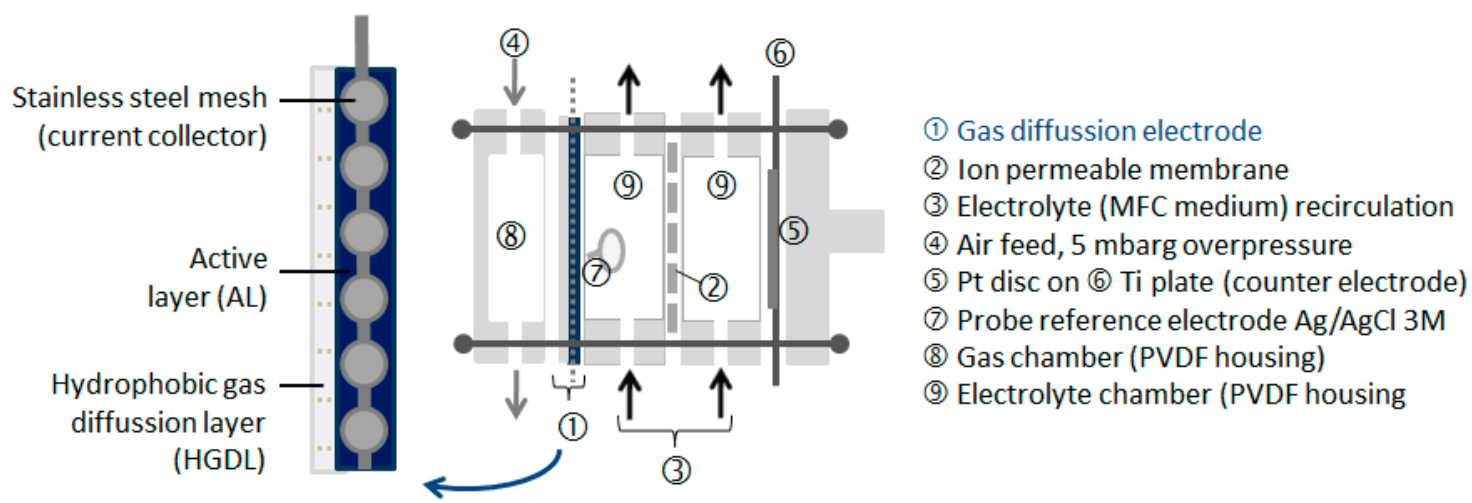

Figure 8. Schematic representation of the cathode half-cell and cross section of the electrode (inset).

For the investigation of the evolution of performance with time, the cathode potential was fixed at $-100 \mathrm{mV}$ vs. $\mathrm{Ag} / \mathrm{AgCl}$ and the cathodic current was monitored on a daily basis. VITO CaSE ${ }^{\mathrm{TM}}$ electrodes (FEP:PSf 75:25 in the HGDL; C:PSf 75:25 and 70:30 respectively in the AL) and one VITO CoRE ${ }^{\mathrm{TM}}$ were tested under identical conditions for comparison purposes.

\subsection{Electrode Characterization in MFC (Full Cell Configuration)}

Full MFC was constructed as described in our previous experiments [26], using a carbon felt anode and an enriched mixed culture as source of inoculum, with a VITO CaSE ${ }^{\mathrm{TM}}$ electrode as cathode. The projected surface area of both the electrode was $10 \mathrm{~cm}^{2}$ and the anodic volume was about $30 \mathrm{~mL}$. The experiments were carried out at room temperature $\left(18^{\circ} \mathrm{C}\right)$ in a batch re-circulated mode with a feed bottle of $800 \mathrm{~mL}$ working volume. Air was fed at an overpressure of 5 mbarg over a water column at the cathode side and the feed bottle was continuously sparged with $\mathrm{N}_{2}$ to create an anaerobic environment at the anode. Initially, MFC was operated in open circuit mode till a stable voltage was observed and then connected across $1 \mathrm{k} \Omega$ resistance to measure the current and power densities. Once the MFC was stabilized in closed circuit, the performance of the MFC was evaluated in terms of polarization. Polarization studies were carried out under a varying external load from $10 \mathrm{k} \Omega$ to $10 \Omega$, measuring the voltage drop and current manually using a digital multi-meter. The respective current and power densities were calculated with respect to the anode surface area and plotted. Shifts in both the anode and cathode potentials were continuously monitored throughout the experiment.

\section{Conclusions}

VITO has developed an electrode manufacturing process based on film casting and phase inversion, which would enable the production of large multilayered electrodes by a continuous manufacturing process. Physico-chemical properties of the electrode's active layers such as total porosity, hydrophilic porosity, and BET surface area maintain a direct relation with their composition (carbonaceous powder and binder used, ratios of carbon) and the fabrication method. The electrodes have been evaluated for application in BESs and compared to electrodes fabricated by cold rolling. A few long duration tests in the cathode half-cell emulating MFC environment demonstrated that the VITO CaSE ${ }^{\mathrm{TM}}$ electrode is more stable than the VITO CoRE ${ }^{\mathrm{TM}}$ electrode. In a full MFC mode, the VITO CaSE ${ }^{\mathrm{TM}}$ electrode showed higher current densities, while the VITO CoRE ${ }^{\mathrm{TM}}$ electrode showed higher power densities. This is due to the differences in carbon percentage in the AL and the porosity of the GDL. The hydrophobicity of the VITO CaSE ${ }^{\mathrm{TM}} \mathrm{AL}$ should be further reduced to the level of the VITO CoRE ${ }^{\mathrm{TM}} \mathrm{AL}$. This is maybe possible by further increasing the amount of $\mathrm{C}$ in the active layer. For final improvement, the fine tuning of the hydrophobic and hydrophilic capillaries will be necessary. The possibility of casting the AL in one run with the HGDL is under investigation. Material choice and parameters used for the casting process can be adapted in order to produce gas diffusion electrodes tailored for other electrochemical applications. 
Acknowledgments: This work was supported funded by the Flemish Agency for Innovation by Science and Technology (IWT) under contract number 090027 and by VITO's strategic research fund. Sandipam Srikanth gratefully acknowledges the Marie-Curie International Incoming Fellowship (IIF) supported project ELECTROENZEQUEST (Grant No: 330803) from the European Commission. The authors wish to thank: André-Viktor Claes, Christof Porto-Carrero (Lab. assistance); Raymond Kemps (SEM), Anne-Marie De Wilde (BET).

Author Contributions: Philippe Vermeiren, Yolanda Álvarez-Gallego, Deepak Pant, Sandipam Srikanth, Karolien Vanbroekhoven and Inge Genné conceived and directed the experiments. Yolanda Álvarez-Gallego and Sandipam Srikanth performed the experiments. Philippe Vermeiren, Yolanda Álvarez-Gallego Xochitl Domínguez-Benetton and Sandipam Srikanth analyzed the data and co-wrote the manuscript draft. Karolien Vanbroekhoven and Inge Genné revised critically the first draft. All the authors discussed the results and contributed to the preparation of the final manuscript.

Conflicts of Interest: The authors declare no conflict of interest. The founding sponsors had no role in the design of the study; in the collection, analyses, or interpretation of data; in the writing of the manuscript, and in the decision to publish the results.

\section{Abbreviations}

The following abbreviations are used in this manuscript:

$\begin{array}{ll}\text { AL } & \text { (electrochemically) active layer } \\ A_{W} & \text { Absorption coefficient } \\ \text { CDP } & \text { cell design point } \\ \text { CFP } & \text { capillary flow porometry } \\ \text { FEP } & \text { Fluorinated ethylene propylene } \\ \text { GDE } & \text { Gas diffusion electrode } \\ \text { HGDL } & \text { hydrophobic gas diffusion layer } \\ \text { LP } & \text { Liquid Permeability } \\ \text { LSV } & \text { Linear Sweep Voltammetry } \\ \text { MES } & \text { Microbial Electrochemical System } \\ \text { MFC } & \text { Microbial Fuel Cell } \\ \text { NEP } & \text { N-Ethylpyrrolidone } \\ \text { ORR } & \text { oxygen-reduction reaction } \\ \text { PSf } & \text { Polysulfone } \\ \text { PTFE } & \text { Polytetrafluoroethylene } \\ \text { SBET } & \text { BET Specific Surface Area } \\ \text { SEM } & \text { Scanning Electron Microscopy }\end{array}$

\section{References}

1. Logan, B.E.; Hamelers, B.; Rozendal, R.; Schroder, U.; Keller, J.; Freguia, S.; Aelterman, P.; Verstraete, W.; Rabaey, K. Microbial fuel cells: Methodology and technology. Environ. Sci. Technol. 2006, 40, 5181-5192. [CrossRef] [PubMed]

2. Pant, D.; Singh, A.; Van Bogaert, G.; Alvarez Gallego, Y.; Diels, L.; Vanbroekhoven, K. An introduction to the life cycle assessment (LCA) of bioelectrochemical systems (BES) for sustainable energy and product generation: Relevance and key aspects. Renew. Sustain. Energy Rev. 2011, 15, 1305-1313. [CrossRef]

3. Pant, D.; Van Bogaert, G.; Diels, L.; Vanbroekhoven, K. A review of the substrates used in microbial fuel cells (MFCs) for sustainable energy production. Bioresour. Technol. 2010, 101, 1533-1543. [CrossRef] [PubMed]

4. Nevin, K.P.; Richter, H.; Covalla, S.F.; Johnson, J.P.; Woodard, T.L.; Orloff, A.L.; Jia, H.; Zhang, M.; Lovley, D.R. Power output and columbic efficiencies from biofilms of Geobacter sulfurreducens comparable to mixed community microbial fuel cells. Environ. Microbiol. 2008, 10, 2505-2514. [CrossRef] [PubMed]

5. Bullen, R.A.; Arnot, T.C.; Lakeman, J.B.; Walsh, F.C. Biofuel cells and their development. Biosens. Bioelectron. 2006, 21, 2015-2045. [CrossRef] [PubMed]

6. Zhou, M.; Chi, M.; Luo, J.; He, H.; Jin, T. An overview of electrode materials in microbial fuel cells. J. Power Sources 2011, 196, 4427-4435. [CrossRef]

7. Guerrini, E.; Grattieri, M.; Faggianelli, A.; Cristiani, P.; Trasatti, S. PTFE effect on the electrocatalysis of the oxygen reduction reaction in membraneless microbial fuel cells. Bioelectrochemistry 2015, 106, 240-247. [CrossRef] [PubMed]

8. Pant, D.; Van Bogaert, G.; Porto-Carrero, C.; Diels, L.; Vanbroekhoven, K. Anode and cathode materials characterization for a microbial fuel cell in half cell configuration. Water Sci. Technol. 2011, 63, 2457-2461. [CrossRef] [PubMed] 
9. Hao, Y.E.; Cheng, S.; Scott, K.; Logan, B.E. Microbial fuel cell performance with non-Pt catalysts. J. Power Sources 2007, 171, 275-281. [CrossRef]

10. Zhang, L.-X.; Liu, C.-S.; Zhuang, L.; Li, W.-S.; Zhou, S.-G.; Zhang, J.T. Manganese dioxide as an alternative cathode catalyst to platinum in microbial fuel cells. Biosens. Bioelectron. 2009, 24, 2825-2829. [CrossRef] [PubMed]

11. Zhang, F.; Cheng, S.; Pant, D.; Van Bogaert, G.; Logan, B.E. Power generation using an activated carbon and metal mesh cathode in a microbial fuel cell. Electrochem. Commun. 2009, 11, 2177-2179. [CrossRef]

12. Forti, J.C.; Rocha, R.S.; Lanza, M.R.V.; Bertazzoli, R. Electrochemical synthesis of hydrogen peroxide on oxygen-fed graphite/PTFE electrodes modified by 2-ethylanthraquinone. J. Electroanal. Chem. 2007, 601, 63-67. [CrossRef]

13. McLean, G.F.; Niet, T.; Prince-Richard, S.; Djilali, N. An assessment of alkaline fuel cell technolgy. Int. J. Hydrogen Energy 2002, 27, 507-526. [CrossRef]

14. Bidault, F.; Brett, D.J.L.; Middleton, P.H.; Brandon, N.P. Review of gas diffusion cathodes for alkaline fuel cells. J. Power Sources 2009, 187, 39-48. [CrossRef]

15. Yang, W.; He, W.; Zhang, F.; Hickner, M.A.; Logan, B.E. Single-Step Fabrication Using a Phase Inversion Method of Poly(vinylidene fluoride) (PVDF) Activated Carbon Air Cathodes for Microbial Fuel Cells. Environ. Sci. Technol. Lett. 2014, 1, 416-420. [CrossRef]

16. Yang, W.; Kim, K.-Y.; Logan, B.E. Development of carbon free diffusion layer for activated carbon air cathode of microbial fuel cells. Bioresour. Technol. 2015, 197, 318-322. [CrossRef] [PubMed]

17. Vermeiren, P.; Moreels, J.P.; Claes, A.; Beckers, H. Electrode diaphragm electrode assembly for alkaline water electrolysers. Int. J. Hydrogen Energy 2009, 34, 9305-9315. [CrossRef]

18. Alvarez, G.Y.; Vermeiren, Y.; Claes, A.V.; Adriansens, W. Gas Diffusion Electrode, Method of Producing Same, Membrane Electrode Assembly Comprising Same and Method of Producing Membrane Electrode Assembly Comprising Same. U.S. Patent 9105933 B2, 11 August 2015.

19. Mulder, M. Basic Principles of Membrane Technology; Kluwer Academic Publishers: Dordrecht, The Netherlands, 1991.

20. Yasuda, H.; Tsai, J.T. Pore size of microporous polymer membranes. J. Appl. Polym. Sci. 1974, 18, 805-819. [CrossRef]

21. Doi, S.; Hamanaka, K. Pore size control technique in the spinning of polysulfone hollow fiber ultrafiltration membranes. Desalination 1991, 80, 167-180. [CrossRef]

22. Radovanovic, P.; Thiel, S.; Hwang, S. Formation of asymmetric polysulfone membranes by immersion precipitation. J. Membr. Sci. 1992, 65, 231-246. [CrossRef]

23. Vermeiren, P.; Leysen, R.; Beckers, H.; Moreels, J.P.; Claes, A. The influence of manufacturing parameters on the properties of macroporous Zirfon ${ }^{\circledR}$ separators. J. Porous Mater. 2008, 15, 259-264. [CrossRef]

24. Mulder, G.; Coenen, P.; Martens, A.; Spaepen, J. The development of a $6 \mathrm{~kW}$ fuel cell generator based on alkaline fuel cell technology. Int. J. Hydrogen Energy 2008, 33, 3220-3224. [CrossRef]

25. Pant, D.; Van Bogaert, G.; De Smet, M.; Diels, L.; Vanbroekhoven, K. Use of novel permeable membrane and air cathodes in acetate microbial fuel cell. Electrochim. Acta 2010, 55, 7710-7716. [CrossRef]

26. ElMekawy, A.; Srikanth, S.; Vanbroekhoven, K.; De Wever, H.; Pant, D. Bioelectro-catalytic valorization of dark fermentation effluents by acetate oxidizing bacteria in bioelectrochemical system. J. Power Sources 2014, 262, 183-191. [CrossRef]

27. Alvarez-Gallego, Y.; Dominguez-Benetton, X.; Pant, D.; Diels, L.; Vanbroekhoven, K.; Genné, I.; Vermeiren, P. Development of gas diffusion electrodes for cogeneration of chemicals and electricity. Electrochim. Acta 2012, 82, 415-426. [CrossRef]

28. Song, C.; Zhang, J. Electrocatalytic oxygen reduction reaction in PEM Fuel Cell. In Electrocatalysts and Catalyst Layers; Zhang, J., Ed.; Springer Verlag: London, UK, 2008; pp. 89-134.

29. Cifrain, M.; Kordesch, K.V. Advances, aging mechanism and lifetime in AFCs with circulating electrolytes. J. Power Sources 2004, 127, 234-242. [CrossRef]

30. Wang, X.; Feng, Y.; Ren, N.; Wang, H.; Lee, H.; Li, N.; Zhao, Q. Accelerated start-up of two-chambered microbial fuel cells: Effect of anodic positive poised potential. Electrochim. Acta 2009, 54, 1109-1114. [CrossRef]

31. Srikanth, S.; Mohan, S.V. Influence of terminal electron acceptor availability to the anodic oxidation on the electrogenic activity of microbial fuel cell (MFC). Bioresour. Technol. 2012, 123, 480-487. [CrossRef] [PubMed] 
32. Pasupuleti, S.B.; Srikanth, S.; Venkata Mohan, S.; Pant, D. Development of exoelectrogenic bioanode and study on feasibility of hydrogen production using abiotic VITO-CoRE ${ }^{\mathrm{TM}}$ and VITO-CASE ${ }^{\mathrm{TM}}$ electrodes in a single chamber microbial electrolysis cell (MEC) at low current densities. Bioresour. Technol. 2015, 195, 131-138. [CrossRef] [PubMed]

33. Zhang, F.; Pant, D.; Logan, B.E. Long-term performance of activated carbon air cathodes with different diffusion layer porosities in microbial fuel cells. Biosens. Bioelectron. 2011, 30, 49-55. [CrossRef] [PubMed]

34. Zhang, X.; Pant, D.; Zhang, F.; He, J.L.; Logan, B.E. Long-Term Performance of Chemically and Physically Modified Activated Carbons in Air Cathodes of Microbial Fuel Cells. ChemElectroChem 2014, 1, 1859-1866. [CrossRef] article distributed under the terms and conditions of the Creative Commons Attribution (CC-BY) license (http:/ / creativecommons.org/licenses/by/4.0/). 